\title{
Lead in Agricultural Soils and Cultivated Pastures Irrigated with River Water Contaminated by Mining Activity
}

\author{
Edith Orellana' ${ }^{1}$, María Custodio ${ }^{1}$, María Carolina Bastos ${ }^{2}$, Walter Cuadrado' \\ 1 Universidad Nacional del Centro del Perú, Av. Mariscal Castilla 3909, Huancayo, Perú \\ 2 Centro Internacional de la Papa - CIP, Huancayo, Perú \\ * Corresponding author's e-mail: eporellana@uncp.edu.pe
}

\begin{abstract}
Agricultural soils that have been irrigated with the contaminated water from metallurgical mining activities for more than 70 years constitute an environmental problem as well as a concern for food security and human health. The presence of lead in the soil and cultivated pastures is highly dangerous, due to its toxicity, persistence and accumulation in plants and animals (cattle). This element enters the trophic chain of humans due to the intake of meat, milk and its derivatives. The concentration of lead was determined in the soil and the cultivated pastures with Lolium x hybridum Hausskn and Medicago sativa $\mathrm{L}$. The soil and pastures samples collected from plots irrigated with river water contaminated with heavy metals at a depth of $0-20 \mathrm{~cm}$. The content of $\mathrm{Pb}$ determined by the atomic absorption spectrophotometry. The results showed the lead concentrations in soil in the range of environmental quality standards for soils according to Peruvian regulations. In the soil with L. x hybridum and M. sativa the average content of lead was $57.17 \pm 6.29 \mathrm{mg} \cdot \mathrm{kg}^{-1}$ and $57.19 \pm 8.99 \mathrm{mg} \cdot \mathrm{kg}^{-1}$; in the above-ground tissues were $1.17 \pm 0.69 \mathrm{mg} . \mathrm{kg}^{-1}$ and $1.62 \pm 0.68 \mathrm{mg} \cdot \mathrm{kg}^{-1}$, respectively. In addition, no significant differences were observed in the $\mathrm{Pb}$ content in the soil and plant tissues. The bioconcentration factor $(\mathrm{BCF})$ in the above-ground tissues of L. $x$ hybridum and M. sativa was less than one and they were not significant. Therefore, irrigation with long-term contaminated water is not a concern for the farmers in the Mantaro Valley.
\end{abstract}

Keywords: lead, accumulation, Lolium x hybridum (rye grass), Medicago sativa (alfalfa), bioconcentration

\section{INTRODUCTION}

Lead is extremely toxic and can be easily introduced into the food chain through plants [Hesami et al. 2018, Piechalak et al. 2002, Wierzbicka and Antosiewicz 1993]. It is one of the most dangerous elements in the environment, due to its persistence in the soil from 1000 to 3000 years [ATSDR 2019, Bowen 1979]. It is an environmental threat because it is an important pollutant in the terrestrial and aquatic ecosystems [Sharma and Dubey, 2005]. In the soil solution, it can easily move from the upper to the lower horizons, causing the contamination of groundwater [Alumaa et al. 2002]. Lead is a very toxic metal for plants with a toxicity threshold of less than one $\mu \mathrm{M}$, almost as much as mercury $(\mathrm{Hg})$ [Kopittke et al. 2010]. Not only does it affect the growth of plants and productivity, but also the food chain, putting the health risk of humans and animals [Khan et al. 2019, Sahi et al. 2002, Xu et al. 2017].

Most contaminated soils contain various pollutants due to the anthropogenic activities, such as the discharge of foundry waste and lead classifies as the second most polluting substance [Liu et al. 2015]. The soil adsorbs lead in different degrees, depending on the content of organic matter, carbonate, clay minerals, oxides of Mn, hydroxides of $\mathrm{Fe}$ and $\mathrm{Al}$ and mineralogical characteristics [Kabata-Pendias 2011, Sipos et al. 2005]. The mobilization of lead is generally slow, but the increase in acidity, the formation of lead-organic matter complexes can increase its solubility [Kabata-Pendias 2011].

The availability of lead by the plants depends on the soil conditions such as the size of its particles, the capacity of cation exchange, the content of organic matter [Davies 1987]. On the other 
hand, the root surface of the plant, root exudates, mycorrhization and transpiration rate affect the availability and absorption of lead [Davies 1987, Lee et al. 2013]. The absorption of lead is greater in roots than in other parts of plants [Sharma and Dubey 2005]. The absorption of lead and its translocation vary significantly among plant species; the roots of the dicotyledons accumulate significantly higher concentrations of lead than the roots of the monocotyledons [Huang and Cunningham 1996, Jia et al. 2010]. The absorption of $\mathrm{Pb}$ by the tissues of the root is mainly intracellular and the metal can accumulate in the vacuoles [Meyers et al. 2008].

In Peru, in the Mantaro Valley (rural sector), the main economic activity is livestock and agriculture, the production of which depends on the water resource of the Mantaro River for the irrigation of their agricultural crops and pastures grown in times of low water. However, this resource is increasingly scarce because the mining and metallurgical activity in the upper Mantaro River basin contributes significantly to the contamination of its surface waters by the discharge of its effluents into the rivers. The use of water contaminated with heavy metals for irrigation of crops for 70 years, consequently brings the concentration of these elements in the soil, in the plants and in the aquatic ecosystems, causing the deterioration of the quality of the soil and water. Considering that, there is still a gap in the knowledge on the $\mathrm{Pb}$ content in the soil and the two species grown under irrigation in the Mantaro Valley.
The objective of the study was to determine the concentration of $\mathrm{Pb}$ in agricultural soils and cultivated pastures (M. sativa and L. x hybridum) irrigated with the river water contaminated with heavy metals.

\section{MATERIAL AND METHODS}

The study was carried out in agricultural plots with cultivated pastures irrigated in dry season with the contaminated water from the Mantaro river since 1945 [Ministry of Agriculture 2011]. The source of water pollution involves the discharges of mining and metallurgical effluents in the upper and middle watersheds of the Mantaro River. The area studied is located in the town of Apata, belonging to the province of Jauja, department of Junín; located on the left bank of the Mantaro valley, S11 '51'21" and W $75^{\circ} 21^{\prime} 25^{\prime}$ " at $3332 \mathrm{~m}$ (Figure 1). The main economic activity of the population in the field of study is agriculture (maize, potatoes and cultivated pastures) and livestock (cattle rearing).

Seventeen plots with cultivated pastures of different size selected, 10 plots with Lx hybridum (0.361-0.916 ha) and seven plots with M. sativa $(0.202-0.338 \mathrm{ha})$. These species were selected because they are a food source for the milk-producing cattle and their derivatives. The samples in general collected in August 2016. The soil samples collected from the $20 \mathrm{~cm}$ of the upper level,

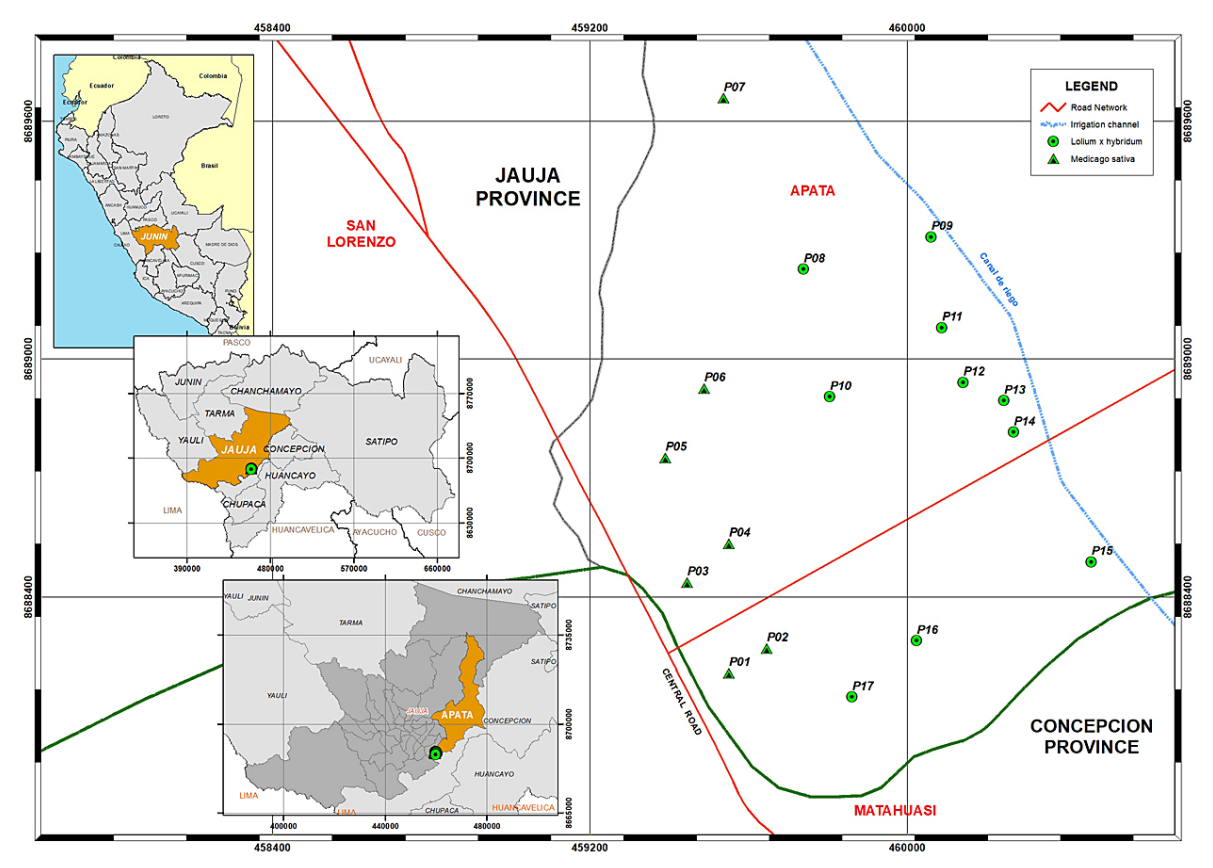

Figure 1. Location map and sampling points 
after removing the first layer of the soil surface. Five soil sub-samples were extracted from each plot, which were then mixed and homogenized to extract a composite sample of $1 \mathrm{~kg}$. Each sample composed of soil was air dried, sieved and homogenized. Then, the soil texture was determined [Bouyoucos 1962], the $\mathrm{pH}$ was established using the ratio 1: $2.5 \mathrm{soil} / \mathrm{H}_{2} \mathrm{O}$ [Thomas 1996], the capacity of cation exchange (CIC) was determined by the saturation method with ammonium acetate [Rhoades 1982] and the content of organic matter through the Walkley-Black method [Walkley and Black 1934].

In order to determine the lead content in the soil, $500 \mathrm{~g}$ of soil collected from each plot, dried at room temperature and sieved. The total concentration of lead in the soil determined using $5 \mathrm{~g}$ of dry soil the samples subjected to digestion with $\mathrm{HNO}_{3}$ [APHA, AWWA,WEF 2012]. After digestion, the concentration of lead was determined with the atomic absorption spectrophotometer. From the same soil sampling points as in the previous stage, $500 \mathrm{~g}$ of fresh samples of plant tissue of each species (above-ground part of animal consumption) of the same age (4 months) were collected. The leaves and stems samples were washed three times with distilled water, subjected to a drying process in a drying oven at a temperature of $60^{\circ} \mathrm{C}$ for $48 \mathrm{~h}$ until constant weight. Then, the grinding carried out, sifted through a $2 \mathrm{~mm}$ mesh screen and a subsequent destruction of the organic matter. In order to determine the content of lead in the plant, $5 \mathrm{~g}$ of dry sample weighed, which was subjected to a process of digestion with $\mathrm{HNO} 3$ and the concentration of lead was determined by means of atomic absorption spectrophotometry [APHA 1998].

The amount of lead absorbed by the plants irrigated with contaminated water was calculated using the bioconcentration factor $(\mathrm{BCF})$ that several authors use. The relation is equal to $\mathrm{BCF}=$ Cplanta /Csuelo where Cplanta is equal to the concentration of the metal in the plant and Csuelo is the concentration of the metal in the soil where the plant grows [Castro et al. 2018, Kicinska 2019]. The means of concentration of lead in the soil and pastures compared using the $t$ test by means of the SPSS statistical package for data processing.

\section{RESULTS AND DISCUSSION}

Physical and chemical characteristics of soil with cultivated pastures

More than $80 \%$ of the soils have medium textures and in lower proportion moderately thick texture. The soil $\mathrm{pH}$ varies from slightly acidic (6.45) to neutral (6.95-7.96) with an electrical conductivity (CE) below one, which indicates that these soils have no salinity problems, organic matter content below $2 \%$ and low cation exchange capacity below 15\% (Table 1).

\section{Concentration of lead in the soil}

The concentration of lead in soil with the culture of L. $x$ hybridum varies from 47.65 to $67.02 \mathrm{mg} \cdot \mathrm{kg}^{-1}$ of soil, with an average of $57.17 \mathrm{mg} \cdot \mathrm{kg}^{-1}$ and with $M$. sativa culture from 43.70 to $67.30 \mathrm{mg} \cdot \mathrm{kg}^{-1}$ of soil, with an average concentration of 59.10 mg.kg-1 (Figure 2). Both concentrations are below the Peru's soil environmental quality standards $\left(70 \mathrm{mg} . \mathrm{kg}^{-1}\right)$ (D.S. No. 002-2013-MINAM 2013) [Ministry of the Environment 2013]. No significant differences were detected in the lead content between soils with L. x hybridum and M. sativa, the presence of cultivated pastures did not influence the concentration of lead in the soil.

Soils had the lead concentrations below the maximum permitted levels, coinciding with the results obtained by [Al-Rashdi \& Sulaiman, 2013]; this could attributed to the size of the soil particles. The greater adsorption and persistence of lead occurs in fine textured soils; also, heavy

Table 1. Mean and standard deviation of the chemical-physical parameters of the soil with cultivated pastures

\begin{tabular}{|l|c|}
\hline \multicolumn{1}{|c|}{ Parameters } & Mean \pm SD \\
\hline Sand $(\%)$ & $47.33 \pm 5.16$ \\
\hline Silt $(\%)$ & $24.17 \pm 4.91$ \\
\hline Clay $(\%)$ & $28.50 \pm 7.71$ \\
\hline Textural class & $\begin{array}{c}\text { sandy loam }- \text { clay loam }- \\
\text { sandy clay loam }\end{array}$ \\
\hline pH & $7.14 \pm 0.49$ \\
\hline EC (dS/m) & $0.29 \pm 0.09$ \\
\hline OM $(\%)$ & $1.15 \pm 0.26$ \\
\hline CEC (meq/100g) & $10.54 \pm 1.21$ \\
\hline
\end{tabular}

SD (standard deviation), EC (electrical conductivity), OM (organic matter), CEC (cation exchange capacity) $(\mathrm{n}=6)$ 


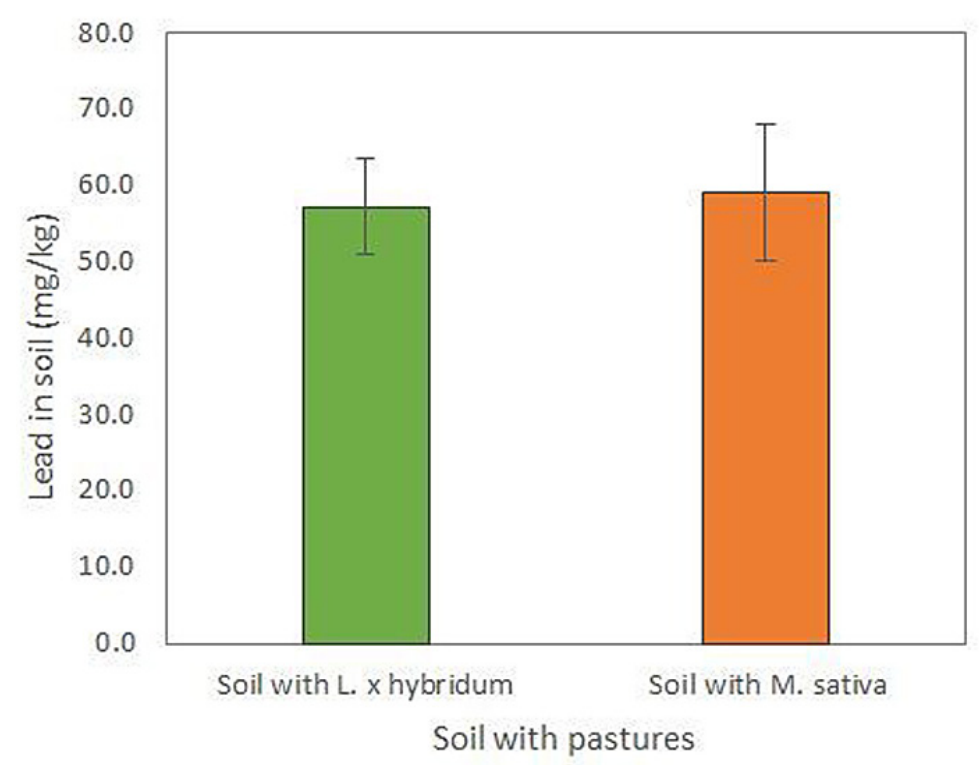

Figure 2. Concentration of lead in the soils with L.x

metals such as lead are not immobilized in soils of thick textural classes [Ebrahim et al. 2016]. On the other hand, the stoppage of activities in $75 \%$ of the La Oroya Metallurgical Complex operated by the company Doe Run Peru has occurred since 2012. It would have contributed to the reduced contamination of the irrigation water of the crops because the content of lead in the irrigation water in 2014 was $0.08 \mathrm{mg} \cdot \mathrm{L}^{-1}$ [Orellana and Erazo 2017] above the environmental quality standards for vegetable irrigation and animal drink.

\section{Concentration of lead in cultivated pastures}

The soils in which forage was cultivated showed higher lead values than those found in the plant. The average concentration of lead in L. x hybridum and M. sativa was 1.17 and $1.62 \mathrm{mg} \mathrm{kg}^{-1}$, respectively. The content of lead in forages was found in the range of 0.13 to $2.35 \mathrm{mg} . \mathrm{kg}^{-1}$ for L. $x$ hybridum and 0.75 to $2.70 \mathrm{mg} \mathrm{kg}^{-1}$ in $M$. sativa (Figure 3). These values are within the limits allowed by the Food and Agriculture Organization of the United, FAO [2003] M. sativa recorded higher values of lead than L. x hybridum. The concentration of lead was lower in the plant compared to what was found in the soil coinciding these results obtained by LaraViveros et al. [2015]. The contribution of heavy metals to the soil occurs every 15 days that is the frequency of irrigation in the Mantaro valley. No significant differences were observed in the accumulation of lead between the pastures studied.
Jadia y Fulekar [2008] reported the lead content in alfalfa of $0.098 \mathrm{mg} \mathrm{kg}^{-1}$ lower than the other metals they studied and what was found in this study. Bytyqi y Sherifi [2010] recorded $0.16-0.24 \mathrm{mg} \mathrm{kg}^{-1}$. Yahaghi et al. [2019] reported high absorption of soluble lead by $M$. sativa and recommend the addition of bacteria to stimulate the development of the plant under adverse environmental conditions, such as heavy metal contamination. Zhang et al. [2017] reported the lead concentrations in ryegrass (L. perenne) shoots $\mathrm{f}$ $5.88 \pm 34.38 \mathrm{mg} \mathrm{kg}^{-1}$ higher than found in this study. Kwiatkowska-Malina and Maciejewska [2013] reported the lead content in L. multiflorum from 7.9 to $10.6 \mathrm{mg} \mathrm{kg}^{-1}$ that varied significantly under various conditions and interactions of environmental factors.

M. sativa (alfalfa) could successfully extract metals and metalloids, so it would not be advisable to consume them by animals because of the transfer to the food chain [Tabasi et al. 2017]. Lead is not an essential element in the nutrition of plants and is generally present in low concentrations in plant tissues; therefore, the accumulation or hyperaccumulation of lead by plants is an extremely rare event (Baker \& Brooks, 1989).

\section{Bioconcentracion factor}

The bioconcentration of lead in the aboveground part of the plant tissue is shown in Figure 4. The BCF for $L . x$ hybridum and $M$. sativa was less than one $(0.0025-0.0402)$. These 


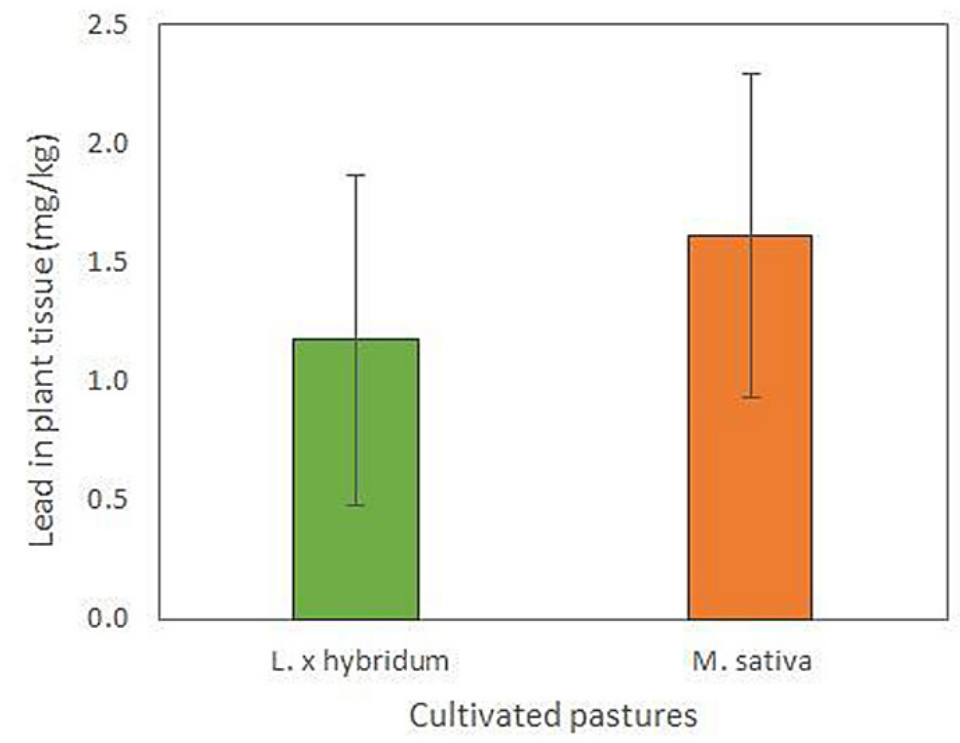

Figure 3. Accumulation of lead in the above-ground tissues of hybridum and M. sativa L.x hybridum and M. sativa

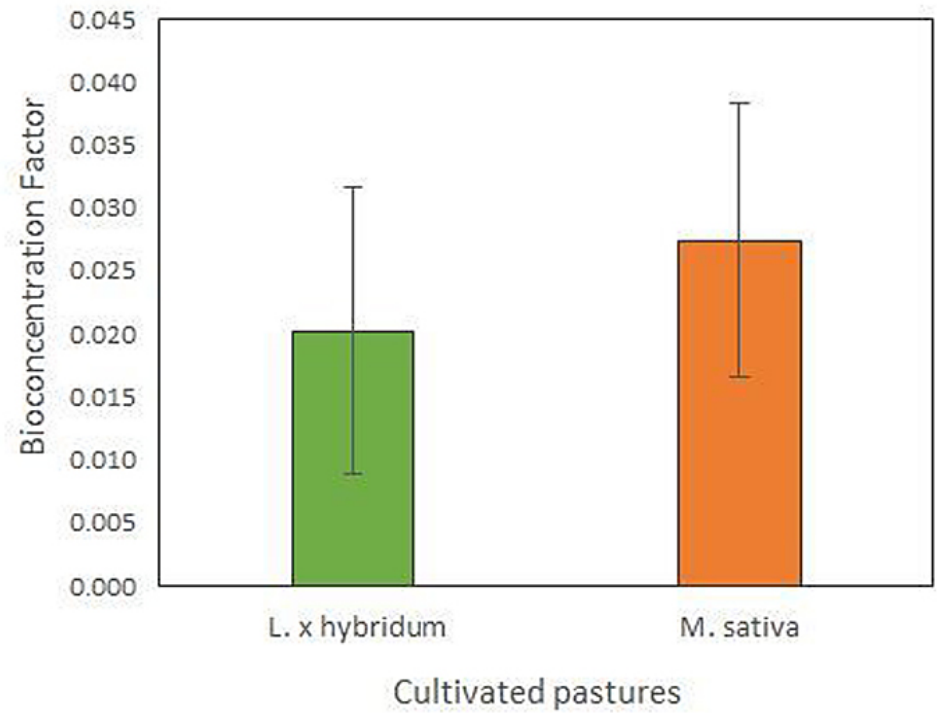

Figure 4. Lead bioconcentration factor (BCF) in the above-ground tissues of L. x hybridum and M. sativa

values are lower than the ones found by Wang et al. [2015] who reported higher values of BCF in the maturation period of alfalfa and that could be attributed to the physiological characteristics of alfalfa, the characteristics of the soils where it develops, the concentration of heavy metals and environmental conditions.

No significant differences were detected in the bioconcentration of lead in both species; however, $M$. sativa registers higher values. Zhang et al. [2019] in L. perenne reported higher BCF $(0.004-0.19)$ than found in this study but less than 1; likewise Cao et al. [2016] reported the values of 0.082 in untreated soils. Al-Rashdi y Sulaiman [2013] in M. sativa recorded values of 0.58 to 2.13 in the above-ground part of the plant. Elouear et al. [2016] indicates that alfalfa plants could not be feasible for the extraction of lead because the values of $\mathrm{BCF}$ were less than one coinciding with the results found.

The results of the study show that $M$. sativa has the ability to retain the maximum concentrations of lead in the roots and to restrict its translocation to shoots and leaves [Aslam et al. 2015]. In legumes, the roots were the main accumulation site [Piechalak et al. 2002]; and the values found 
are indicative of the lower mobility of the soil to the plant and the species studied are not hyperaccumulators and there is a low risk that lead transferred significantly to the plant.

\section{CONCLUSIONS}

The concentrations of lead in the soil with pastures cultivated and irrigated with contaminated water were low; they did not exceed the maximum limits recommended by the environmental quality standards for soil. The accumulation of lead in L. x hybridum and M. sativa did not exceed the permissible limits. These species are fodder crops of importance for Apata's livestock; they are used as main fodder for cattle. The low values of lead in their tissues do not constitute a risk to animals that consume it. However, the content of other heavy metals should be regularly monitored in order to detect the degree of soil and forage contamination.

\section{Acknowledgment}

The authors thank the National University of the Center of Peru for the facilities provided during the development of the research and the farmers of Apata, Jauja for the providedinformation.

\section{REFERENCES}

1. Agency for Toxic Substances and Disease Registry (ATSDR). 2019. Toxicological profile for lead (Update). Atlanta, GA: U.S. Department of Health and Human Services, Public Health Service

2. Al-Rashdi, TT., Sulaiman, H. 2013. Bioconcentration of heavy metals in alfalfa (Medicago sativa) from farm soils around Sohar Industrial area in Oman. APCBEE Procedia, 5, 271-278. https://doi. org/10.1016/j.apcbee.2013.05.047

3. Alumaa, P., Petersell, V., Steinnes, E. 2002. Short Communication Sorption of toxic heavy metals to soil. International Journal of Hygiene and Environmental Health, 204, 375-376. https://doi. org/10.1078/14384630222269440

4. APHA, AWWA, WEF. 1998. Standard methods for the examination of water and wastewater. 22nd ed. Washington: American Public Health Association.

5. Aslam, S., Sharif, F., Khan, A. U. 2015. Effect of lead and cadmium on growth of Medicago sativa L. and their transfer to food Chain. Journal of Animal and Plant Sciences, 25(2), 472-477.

6. Baker, A., Brooks, R. 1989. Terrestrial higher plants which hyperaccumulate metallic elements
- a review of their distribution, ecology and phytochemistry. Biorecovery, 1(2), 81-126. https://doi. org $/ 10.1093 /$ toxsci/kfg 183

7. Bouyoucos, GJ. 1962. Hydrometer method improved for making particle size analysis of soils. Agronomy Journal, 54(5), 464-465. https://doi.org/DOI:10.2134/ agronj1962.00021962005400050028x

8. Bowen, HJM. 1979. Environmental chemistry of the elements. London: Academic Press.

9. Bytyqi, A., Sherifi, E. 2010. Cadmium and lead accumulation in alfalfa (Medicago sativa L .) and their influence on the number of stomata. Materials and Technology, 44(5), 277-282.

10. Cao, S., Wang, W., Zhao, Y., Yang, S., Wang, F., Zhang, J., Sun, Y. 2016. Enhancement of lead phytoremediation by perennial ryegrass (Lolium perenne L .) using agent of Streptomyces pactum Act12. J Pet Environ Biotechnol, 7(2), 269-275. https://doi.org/10.4172/2157-7463.100026

11. Castro, N., Moreno, R., Calderón, F., Moreno, A., Tamariz, J. 2018. Heavy metals in milk from cows fed with alfalfa produced in soils irrigated with wastewater in en Puebla and Tlaxcala, México. Mexican Journal of Pecuary Sciences, 9(3), 466-485. https:// doi.org/10.22319/rmcp.v9i3.4358. (in spanish)

12. Davies, BE. 1987. Consequences of environmental contamination by lead mining in Wales. Hydrobiologia, 149(1), 213-220. https://doi.org/10.1007/ BF00048662

13. Ebrahim, J E., Salih, A A., Abahussain, A. 2016. Effect of long-term irrigation using treated wastewater on heavy metal contents of soils grown to Medicago sativa in the Kingdom of Bahrain. International Journal of Agronomy and Agricultural Research, 4, 20-29.

14. Elouear, Z., Bouhamed, F., Boujelben, N., Bouzid, J. 2016. Application of sheep manure and potassium fertilizer to contaminated soil and its effect on zinc, cadmium and lead accumulation by alfalfa plants. Sustainable Environment Research, 5-9. https://doi.org/10.1016/j.serj.2016.04.004

15. Food and Agriculture Organization of the United, FAO. (2003). Users manual for irrigation with treated wastewater. Cairo.

16. Hesami, R., Salimi, A., Ghaderian, S. M. 2018. Lead, zinc, and cadmium uptake, accumulation, and phytoremediation by plants growing around Tang-e Douzan lead-zinc mine, Iran. Environmental Science and Pollution Research, 25(9), 87018714. https://doi.org/10.1007/s11356-017-1156-y

17. Huang, JW., Cunningham, S. D. 1996. Lead phytoextraction: species variation in lead uptake and translocation. New Phytologist, 134(1), 75-84. https://doi.org/10.2307/2558516

18. Jadia, CD., Fulekar, MH. 2008. Phytotoxicity and remediation of heavy metals by Alfalfa ( Medicago sativa ) in soil- vermicompost Media. Advences in Natural and Applied Sciences, 2(3), 141-151.

19. Jia, L., Wang, W., Li, Y., Yang, L. 2010. Heavy metals in soil and crops of an intensively farmed area: A case study in Yucheng City, Shandong Province, 
China. International Journal of Environmental Research and Public Health, 7(2), 395-412. https:// doi.org/10.3390/ijerph7020395

20. Kabata-Pendias, A. 2011. Trace elements in soils and plants. CRC Press. https://doi.org/10.1201/ b10158-25

21. Khan, I., Iqbal, M., Shafiq, F. 2019. Phytomanagement of lead-contaminated soils: critical review of new trends and future prospects. International Journal of Environmental Science and Technology, (0123456789). https://doi.org/10.1007/ s13762-019-02431-2

22. Kicinska, A. 2019. Arsenic, Cadmium, and Thallium Content in the Plants Growing in Close Proximity to a Zinc Works - Long-Term Observations. Journal of Ecological Engineering, 20(7), 61-69. https://doi.org/10.12911/22998993/109866.

23. Kopittke, PM., Blamey, FPC., Asher, CJ., Menzies, NW. 2010. Trace metal phytotoxicity in solution culture : a review. Journal of Experimental Botany, 61(4), 945-954. https://doi.org/10.1093/jxb/erp385

24. Kwiatkowska-Malina, J., Maciejewska, A. 2013. Uptake of heavy metals by darnel multifloral (Lolium multiflorum Lam) at diverse soil reaction and organic matter content. Soil Science Annual, 64(1), 19-23. https://doi.org/10.2478/ssa-2013-0004

25. Lara-Viveros, FM., Ventura-Maza, A., Ehsan, M., Rodríguez-Ortega, A., Landero-Valenzuela, J. VMN. 2015. Content of $\mathrm{Cd}$ and $\mathrm{Pb}$ in soil and plants of different crops irrigated with wastewater in the Mezquital valley, Hidalgo, México. International Journal of Environment Pollution, 31(2), 127-132. (in spanish).

26. Lee, KK., Cho, HS., Moon, YC., Ban, SJ., Kim, JY. 2013. Cadmium and Lead Uptake Capacity of Energy Crops and Distribution of Metals within the Plant Structures. Journal of Civil Engineering, 17, 44-50. https://doi.org/10.1007/ s12205-013-1633-X

27. Liu, D., Li, S., Islam, E., Chen, J., Wu, J., Ye, Z., ... Lu, K. 2015. Lead accumulation and tolerance of Moso bamboo ( Phyllostachys pubescens ) seedlings : Applications of Phytoremediation , 16(2), 123-130. https://doi.org/10.1631/jzus.B1400107

28. Meyers, DER., Auchterlonie, G. J., Webb, R. I., \& Wood, B. 2008. Uptake and localisation of lead in the root system of Brassica juncea. Environmental Pollution, 153, 323-332. https://doi.org/10.1016/j. envpol.2007.08.029

29. Ministry of Agriculture. 2011. Study of the formation of irrigation blocks for the formalization of water use rights in the Mantaro Valley - CIMIRM. Junín, Perú. (in spanish)

30. Ministry of the Environment. 2013. Supreme Decree No. 002, 2013. Approve environmental quality standards (EQS) for soil. Official Gazette El Peruano. (in spanish)

31. Orellana, E., Erazo, R. 2017. Environmental risk of lead accumulation in crops irrigated with water from the Mantaro river, Jauja sector, Perú. In C. A. \& C. Shinn (Ed.), Ecotoxicology in Latin America (pp. 363-376). New York: Nova Science Publisher.
32. Piechalak, A., Tomaszewska, B., Baralkiewicz, D., Malecka, A. 2002. Accumulation and detoxification of lead ions in legumes. Phytochemistry, 60(2), 153-162. https://doi.org/10.1016/ S0031-9422(02)00067-5

33. Rhoades, J. 1982. Cation exchange capacity. In A. L. Page (Ed.), Methods of soil analysis. Parte 2. Madison, Wisconsin: Agronomy Monograph No 9. ASA y SSSA.

34. Sahi, SV, Bryant, NL, Sharma, NC, Singh, S. R. 2002. Characterization of a Lead Hyperaccumulator Shrub , Sesbania drummondii, 36(21), 4676-4680.

35. Sharma, P., Dubey, R. S. 2005. Lead toxicity in plants. Brazi. Journal of Plant Physiology, 17(1), 35-52. https://doi.org/http://dx.doi.org/10.1590/ S1677-0420200500010000.

36. Sipos, P., Németh, T., Mohai, I. 2005. Distribution and possible immobilization of lead in a forest soil ( Luvisol ). Environmental Geochemistry and Health, 27(1), 1-10. https://doi.org/DOI: 10.1007/ s10653-004-1581-y

37. Thomas, GW 1996. Soil pH and Soil Acidity. In D. L. Sparks (Ed.), Methods of Soil Analysis Part 3: Chemical Methods. Madison, Wisconsin: SSSA Book Series 5, Soil Science Society of America.

38. Walkley, A., Black, I. 1934. An examination of the degtjareff method and a proposed modification of the chromic matter and a proposed modification of the chromic acid titration method. Soil Science, 34, 29-38. https://doi.org/http://dx.doi.org/10.1097/00 010694-193401000-00003

39. Wang, F., Li, Y., Zhang, Q., Qu, J. 2015. Phytoremediation of cadmium, lead and zinc by Medicago sativa L . ( alfalfa ): A study of different period. Bulgarian Chemical Communications, 47(D), 167-172.

40. Wierzbicka, M., Antosiewicz, D. 1993. How lead can easily enter the food chain a study of plant roots. The Science of the Total Environment, 423-429. https://doi.org/https://doi.org/10.1016/ S0048-9697(05)80043-9

41. Xu, B., Wang, Y., Zhang, S., Guo, Q., Jin, Y., Chen, J., ... Ma, H. 2017. Transcriptomic and physiological analyses of Medicago sativa L. roots in response to lead stress. PLoS ONE, 12(4), 1-16. https://doi.org/ https://doi.org/10.1371/journal.pone.0175307 April

42. Yahaghi, Z., Shirvani, M., Nourbakhsh, F., Pueyo, J. J. 2019. Uptake and effects of lead and zinc on alfalfa (Medicago sativa L.) seed germination and seedling growth: Role of plant growth promoting bacteria. South African Journal of Botany. https:// doi.org/10.1016/j.sajb.2019.01.006

43. Zhang, W., Yang, J., Li, Z., Zhou, D., Dang, F. 2017. Assessment of the availability of As and $\mathrm{Pb}$ in soils after in situ stabilization. Environmental Science and Pollution Research, 24(29), 23153-23160. https://doi.org/10.1007/s11356-017-9877-5

44. Zhang, Y., Li, F., Xu, W., Ren, J., Chen, S., Shen, K., Long, Z. 2019. Enhanced phytoextraction for co-contaminated soil with $\mathrm{Cd}$ and $\mathrm{Pb}$ by ryegrass (Lolium perenne L.). Bulletin of Environmental Contamination and Toxicology, 103(1), 147-154. https://doi.org/10.1007/s00128-019-02661-7 